http://dx.doi.org/10.18778/1508-1117.24.01

Tolga Levent

\title{
RIS-MERSIN PROJECT: THE FIRST REGIONAL INNOVATION STRATEGY IN TURKEY AND ITS SPATIAL DIMENSIONS
}

\begin{abstract}
Mersin is a relatively new city in Turkey. Although it only dates back to the first decades of the $19^{\text {th }}$ century, it has experienced significant changes in its urban economic structure. Being established as a port city, Mersin has been a major gate for Anatolia and Middle-East. This character has been supported by construction of a new port in 1962 and introduction of new macro-economic preferences towards export-oriented economic development in 1980, both of which not only have increased the number of foreign trade and logistics activities but also have enriched the urban economic structure with new economic activities. With the Persian Gulf Crisis in 1990 and the following embargo, however, there occurred drastic changes in local economic life of Mersin. Logistics activities started to lose their significance due to radical decreases in transactions with Middle-Eastern countries. In 2006, the first regional innovation strategy in Turkey was prepared as the end product of RIS-Mersin Project in order to change downward trends of local economy and trigger local development opportunities. The strategy depends on the idea that innovation is a key-factor for local development. The aim of this study is critical evaluation of this regional innovation strategy and its spatial dimension within the context of local development. Successes and failures of this strategy provide important lessons for other regions aiming to produce such strategies.
\end{abstract}

Key words Mersin, regional innovation strategy, spatial dimension.

\section{Introduction}

Mersin is a relatively new city in Turkey. The emergence of the city of Mersin dated only back to the first decades of $19^{\text {th }}$ century. In that period, the economical conjuncture forced an increase in cotton production in Çukurova Plain. At first, the port of Tarsus was the main port of cotton trade. However, with natural fills of alluvium, this port could not continue its function and the port of Mersin appeared 
as the main option for exporting the agricultural surplus of Çukurova Plain. This was the starting point of development of the city of Mersin. The construction of road connection in 1875 and the railroad connection in 1886 with inner Anatolia had increased development tendencies. With these transportation investments, the city of Mersin became one of the most important gates of Anatolia. This new role increased the number of foreign trade and logistics firms, transportation firms, manufacturing firms, financial services, business services and the consulates organizing foreign trade activities. This tendency had continued until World War I and all of these firms and activities became primary components of economical structure of the city of Mersin in the succeeding periods (Eraydin 2002; Kara 2005; Levent 2009).

After the World War I, the early Republican period was a rapid recovery period for Mersin because of the increasing capacity of foreign trade in the international markets. In this period, besides being an export center for agricultural surplus, Mersin became an import center for foreign industrial products. With these functions, local economical structure strengthened its position until the end of 1920's, where there emerged a series of financial and economical crises within western capitalist economies. These crises decreased the foreign trade capacity of Mersin, as a result of which a period of economical stagnation had started (Eraydin 2002).

After the World War II, the city of Mersin experienced steady but a limited economical development. With the construction of new port in 1962, however, there emerged a significant economical upturn. This new port of Mersin increased export and import activities more than expected (Eraydin 2002). In the second half of 1970's, the port of Beirut started to lose its capacity and economical importance due to the Civil War in Lebanon (Steward 1996). This was one of the basic reasons of shifting certain trade and logistics activities towards the port of Mersin where a relatively safe environment was provided for them. This created a slight economical development, which was remarkably important in the oil-crises period.

With 1980's, Turkey changed its economical development paradigm. This change was from a closed economy of import substitution towards an export oriented open economy (Köse 2002; Levent ve Sar1kaya Levent 2010). It boosted export and import demands of rapidly developing industrial activities, the general result of which was the increasing importance of the city of Mersin within the logistics geography. The free trade zone opened in 1987 was another indirect result of this change and helped to turn the city of Mersin into a major trade center in eastern Mediterranean (Levent 2010).

In 1990's, Persian Gulf Crisis and the following embargo created drastic transformations in the local economic life of Mersin. The decrease of trade with Middle Eastern countries resulted in a major decline in logistics capacity. Moreover, in the same period, due to a series of financial and economical crises, the financial 
capabilities of central government to make investments for supporting the local economies decreased significantly. In such negative conditions, the composition of economical sectors started to change and economical sectors such as agriculture, construction and tourism gained relative importance over against the logistics activities (Levent 2010) which could be considered to be a kind of local economical survival strategy.

In fact, agricultural activities have been important for Mersin from its very first days. The fertile lands surrounding the city and the suitable climatic conditions have supported high levels of agricultural production. Moreover, the emergence of greenhouses in 1980's and their spatial expansion in the following periods promoted the variety of agricultural products and stepped up agricultural production. Both of these changes not only consolidated the position of agricultural sector within the local economical composition, but also created positive impacts upon food industry using local agricultural products (Eraydın 2002).

Like the agricultural activities, construction activities have been also important for the economy of Mersin. There were two main sources for construction activities. The first one was the housing demands of migrants from eastern and southeastern Anatolia. These people came to Mersin for better living conditions and job opportunities than their hometowns. Since their incomes were relatively low, their housing demands mostly triggered informal construction activities. However, there were also the demands of middle income groups from inner Anatolia for a second house in the coastal zone. These demands paired themselves with the construction activities in the formal side. Both of these informal and formal construction activities started to develop with 1970's and peaked between the years of 1980 and 1990. At the end of this period, the employment share of construction in local economical composition reached approximately 6.5\% (Levent 2009). However, this share started to decline with 2000's, not only because of the decrease of the demands from both of these sources, but also due to the entrance of Housing Development Administration of Turkey into the construction market as a major actor instead of local entrepreneurs (Eraydın 2002; Türel 2002).

Tourism has been another sector that should be considered within the local economical composition, at least, due to its potentials. Since 1970's, tourism has been taken into consideration as one of the important income and employment creating sectors in Turkey. However, spatial development policies fostered southwestern coasts of Anatolia as the main focus of tourism investments. Therefore, Mersin has never experienced a tourism development like Antalya until 2000's. With 2000's, tourism has become an option for local development, however, its employment share has never become high as the one of agriculture or construction.

In the first years of 2000's, there was a relative richness in the local economical composition. Logistics activities were still leading sector. However, it is 
not possible to claim that Mersin was a mono-sector city depending upon only logistics activities. There were other economical activities such as agriculture, construction and tourism. The concurrent existence of various activities, however, did not mean that the local economical structure was problem-free. The most vital problems were fragility and vulnerability of economical structure, especially under the conditions of economical crises. These crises created negative impacts not only on logistics activities but also on other sectors, especially on agriculture. In order to eliminate these negative impacts, local stakeholders reached a consensus on innovation which was considered as one of the most significant factors for competitive advantage.

\section{Innovation for Local Development}

Innovation firstly appeared in the economical literature with Schumpeter's studies trying to reveal the capitalist economic order and the mechanisms of competition (Schumpeter 2005). In these studies, innovation was conceptualized as the dominant force in the business cycles and economic development. It was a factor of creating a new production function within the economic mechanisms that realize the investments (Elliot 2005; Schumpeter 2005). After Schumpeter, there were different studies on innovation conducted by various researchers such as J. Schmookler (1966), F.P. Drucker (1985), M.E. Porter (1990). These studies developed different definitions of innovation and focused on different features of innovation. However, almost all of these studies have two common aspects. The first one is that innovation is taken into consideration at the firm level. Due to this limitation, it is difficult to understand the external impacts of economical context on formation of innovation. The second common aspect is that innovation has a power that creates an economic capacity.

Innovation, in general, is considered as the use of new methods in social, cultural and administrative domains (Elçi 2007, p. 1). There are different types of innovation such as product innovation, service innovation, process innovation, organizational innovation, marketing innovation; and different classifications of innovation with reference to the use of technology by making innovation; the level of change obtained through the innovation; and the processes by making innovations (Elçi 2007, p. 3-19). All of these types and classes of innovation are important because of their varying roles in economical development.

Innovation has a social dimension since it creates a tendency to reduce disparities and create employment (Elçi 2007, p. 3). Moreover, it has a spatial dimension due to the interaction between actors carrying knowledge. These two dimensions attach a socio-spatial character to innovation and help innovative milieus and regional innovation systems to be put on the agenda of regional development. 
These regional innovation systems are resistant to economic crises. This is why they are important research topics in regional development studies. These studies, especially, focus on the internal aspects of these innovative milieus and the ways how these regional innovation systems could be produced at different locations. These focuses, at the same time, are the starting points for regional innovation strategies. The ultimate target of these regional innovation strategies is to create a regional innovation system where there is an innovation based local economy. The first step to have this kind of local economy is the improvement of human capital. For the effectiveness of this human capital, investments on communication and transportation infrastructure are promoted. The result is a socially-productive environment which might support new innovative ideas. Accessibility to capital is also important for such environments since innovative activities prefer to be in capital-rich environments. All the policies in these dimensions aim to increase the possibility of innovation by pulling innovative firms and qualified labor into the region. However, they are not solely sufficient. There should be a high level of interaction among different stakeholders such as firms, public institutions, universities and research centers. These stakeholders are important by producing a regional innovation strategy because interactive exchange of knowledge among these knowledge actors is a main feature of regional innovation systems. These dynamic exchanges increase the possibility of competitive advantage which is, sometimes, the only chance for economical survival of the locality (Cooke 1992; Cooke, Uranga and Etxebarria 1998; Elçi 2007).

\section{RIS-Mersin Project and the Regional Innovation Strategy for Local Development}

Within the global economical order, economical competition has occurred not only between the firms, but also between the localities. These localities compete with each other in order to attract qualified labor and physical capital. Innovation, in this framework, is one of the key factors by this attraction (Bölgesel Inovasyon Stratejisi Hazırlama Kılavuzu - Aşama 2, 2007, p. 9).

Innovation has, firstly, entered into the national agenda of Turkey in the beginning of 2000's. Since then, it has been frequently mentioned in projects proposed by public institutions and NGOs, in the National Innovation Strategy of TUBITAK - most important national scientific and technological research institution of Turkey - and recent national plans (Mersin Inovasyon Stratejisi 2006-2016, 2008). Preparing regional innovation strategy for Mersin started with simple facts that economical development in Mersin was below the expected level and Mersin could not use its potentials for economical development although it had certain advantages. The main aims of Mersin Regional Innovation Strategy were to provide a simple and relevant innovation based development framework for local 
stakeholders and to increase the innovation capacity of the city of Mersin and its region (Elçi, Karataylı and Karata 2008, p. 51). The main targets of this Strategy were developing innovation capabilities of firms, increasing the quality of life, creating new work opportunities and achieving sustainable regional economy (Mersin Inovasyon Stratejisi 2006-2016, 2008, p. 3).

\subsection{RIS-Mersin Project}

By considering these aims and targets, RIS-Mersin Project was prepared between 2006 and 2008, the end product of which was Mersin Regional Innovation Strategy as the first attempt in Turkey. There were important stakeholders of the Project headed by Mersin Governorship and coordinated by METUTECH, which was ranked first in Turkey according to technology development zones performance index in 2013. Mersin University, Mersin Chamber of Commerce and Industry, Mersin-Tarsus Organized Industrial District, EPIRUS Innovation Development Center of Greece were the main stakeholders in the Project. However, there were lots of public institutions, NGOs and firms that made contributions to the Project and Strategy within the process (Mersin Inovasyon Stratejisi 2006-2016, 2008).

There were three main stages in the Project. The first one was the "preparation stage". The main aim of this stage was the formation of Project Team. After this Project Team was formed, there were innovation forums, national and international meetings and interviews with the actors and stakeholders to design the process of the Project. All of these efforts helped to introduce the innovation to the public and manufactured a positive public opinion on it (Gök 2009, p. 93; Mersin İnovasyon Stratejisi 2006-2016, 2008, p. 7).

The second stage was the "implementation stage". In this stage, there were various meeting and questionnaires in order to understand the existing situation and the future needs (Metin 2010, p. 71). The data and information obtained from these meetings and questionnaires became the information base for SWOT analysis and action plans, both of which were quite important for the definition of Strategy (Bölgesel İnovasyon Stratejisi Hazırlama Kılavuzu - Aşama 0, 2005, p. 22). After these studies, the vision, the main targets and strategic targets were determined. The vision for the Strategy was "becoming a region of high quality of life with a sustainable economy based on knowledge and innovation". Related to this vision, targets about the stakeholders, patents, innovative firms, R\&D activities, employment structures, potential GNP per capita were defined (Mersin Inovasyon Stratejisi 2006-2016, 2008, p. 9-10). These targets were both qualitative and quantitative. In order to reach these qualitative and quantitative targets, there were strategic targets such as improving innovation system and innovation culture; increasing innovation activities in existing firms and triggering the innovative entrepreneurship; using the regional potentials for key sectors; and developing 
knowledge producers. For each strategic target, there were sub-targets, strategic aims and operational aims in detail (Mersin Inovasyon Stratejisi 2006-2016, 2008, p. 34-45). At this point, the key sectors were determined for innovation based local economy. These sectors were logistics, agriculture-food industry, tourism (Gök 2009, p. 94). For each sector, a sector-specific platform was formed by representatives of relevant public institutions and private firms. According to sector-specific vision, priorities for each sector were determined and various projects were proposed (Mersin Innovation Strategy 2006-2016, 2008). Moreover, policies for innovative development and action plans for each sector were prepared (Gök 2009, p. 94). These action plans were documents that contain concrete actions clarifying implementation of the Strategy (Bölgesel Inovasyon Stratejisi Hazırlama Kılavuzu - Aşama 2, 2007, p. 33). Moreover, there was a responsible leader and a time schedule to be completed for each action (Mersin Inovasyon Stratejisi ve Eylem Planı, 2008).

The last stage of the project was the "evaluation stage". In this stage, the Strategy was defined and implementation mechanisms of the Strategy were formed. There were certain implemented pilot projects (Gök 2009). These were Entrepreneur 33 to support the innovative entrepreneurship; Export 33 in order to educate foreign trade specialists, R\&D 33 in order to support university and firm associations and increase the number of innovative projects and the Innovation Competitions in order to spread innovation culture among firms (Mersin Inovasyon Stratejisi 2006-2016, 2008, p. 60-79).

\subsection{Regional Innovation Strategy}

Since the leading economical sectors in Mersin were quite sensitive to international financial and economical crises, the market initiators and actors wanted to increase the level of thickness of local economical structure as much as possible. The Strategy became vital for the economical future of Mersin, in this sense. It defined the very potential sectors having high level of investability and potentiality of innovation by analyzing existing conditions as much as possible and developed advanced propositions in sector-specific master plans.

The vision of Logistics Master Plan was "making Mersin the starting point of the international freight corridors from north to south and from east to west" (Mersin Lojistik Strateji Planı, 2009). With reference to this vision, the Master Plan had propositions and targets about a freight bridge between Samsun and Mersin, combined transportation activities, logistics base, logistics village, organized industrial district, free trade zone and wholesale site. Additionally, it suggested a new Intraurban Transportation Master Plan considering potential passengers and freights movements and recommended plan modifications in existing 1:100.000 scale regional spatial development plan in order to manage all future implications 
of both Logistics Master Plan and Intraurban Transportation Master Plan on urban space (Mersin Lojistik Strateji Planı, 2009). The general intention to improve the transportation and logistics infrastructure added a spatial dimension to logistics master plan, however, except for the logistics base and logistics village, the innovative capacity of these propositions in logistics were too limited.

The platform of agriculture-food industry proposed Agriculture Master Plan. This platform did not directly focus on food industry since they supposed that the developments in agriculture would support the growth of local food industry. The strategic aims of this Master Plan were about agricultural sub-sectors, income and employment resources in agriculture, the use and marketing of agricultural products, achieving sustainability in agricultural production. All of these aims were consistent with national agriculture strategy of Turkey (Mersin Tarım Master Planı, 2011). The lack of spatial emphasis of the propositions of this Master Plan was, however, quite interesting. There were not any locational decisions about the agricultural investments which created confusions about the investments not only in agriculture but also in food industry.

The general conditions of Tourism Master Plan were similar to Logistics Master Plan and Agriculture Master Plan. In this Master Plan, there were strategies about the socio-cultural, economical and organizational issues of tourism. However, spatial dimension within this Master Plan was also relatively weak. Determining sub-regions of tourism activities in Mersin and general bed capacities in these regions were the only spatial dimension of this conventional Tourism Master Plan (Mersin Illi Turizm Master Planı, 2010) which means that the innovative capacity of this Plan was limited, too.

\section{Conclusions}

Although theoretical studies and practical experiences state that regional innovation strategies are important, it is impossible to claim that they are valid options for all regions. It is not consistent to propose regional innovation strategies for certain underdeveloped regions, yet these strategies might increase the competitive advantage of certain regions having production and innovation capacities.

It is relatively easy to evaluate the process and the results of RIS-Mersin Project since it was completed and presented in several platforms. This evaluation could be helpful for other cities and regions which intend to have a regional innovation strategy through a proper process (Gök 2009, p. 94).

One of the most important results of RIS-Mersin Project is that it was a bottom-up project started with local initiators. Due to this aspect, it triggered local economical enthusiasm (Metin 2010, p. 87). The increase of the local interest directed towards innovation was another positive social outcome of the Project. Through this interest, local stakeholders might have knowledge about the ways how firms 
could be innovative. Moreover, because of its relation to innovation, the city and its local economical environment have become relatively well-known in eastern Mediterranean.

Almost all critical economical stakeholders were involved in the process of Project. This comprehensiveness and subsequent cooperation among these stakeholders resulted in not only proper definitions of the local economical problems, action plans and pilot projects, but also a local public negotiation which could be conceived as the starting point for innovative culture in the city (Levent and Sarıkaya Levent 2011). Another contribution of this comprehensive cooperation among stakeholders was the increase in trust and confidence at local level (Metin 2010, p. 147), which increased the amount of social capital in the locality.

Evaluation of the Strategy, on the other hand, is more difficult since it is not completed yet. Exact evaluations can be done only after the completion of the Strategy. Therefore, only partial evaluations are possible, at the moment.

One of the most important results of the Strategy has been the formation of institutional structure supporting innovation and local innovative culture. This means an institutional thickness for innovative local economies. Some of the elements of these structures are directed to policy formation such as Administration Unit of RIS-Mersin, Regional Innovation Committee, Network of Business Angels and various project offices. The ones directed to use information and knowledge are Sector-Specific Platforms, Agriculture-Food Cluster, Mersin Logistics Center. The ones producing and sharing knowledge are Tourism Research Center, Logistics and Foreign Trade Research Center, Mersin Agriculture and Food Education Center. There are also planned elements of this structure like Innovation Center, Incubation Center, R\&D Innovation Center with which institutional background of innovation will get more stronger (Metin 2010, p. 93-112).

The Strategy has created positive impacts on local labor markets. With reference to the Strategy, there were education programs for logistics and agriculture-food industry platforms, technical incursions for logistics platforms, vocational school on food technology and CV pool for tourism sector. All of these efforts helped to increase the quality of labor and to pull qualified labor into the region (Metin 2010, p. 113-117).

The Strategy has contributions to form associative networks which are important for innovation. At regional scale, the level of association among firms, education and research institutions, public institutions has increased. At national scale, the interest of State Planning Organization and Undersecretariat of Foreign Trade has directed towards the city. Moreover, being a member of international networks such as Innovating Regions of Europe Networks and Enterprise Europe Network has increased the number international projects proposed in Mersin (Metin 2010, p. 118-125). 
Many researchers and local entrepreneurs state that the lack of certain elements of institutional structure, limited contribution of University into the process of the Project, non-existence of Greater Mersin Authority within the process were the basic inadequacies of the Project and Strategy (Gök 2009). However, the most important problem is the lack of spatial dimension of the Strategy (Levent and Sarikaya Levent 2013). „For a local innovative development, what should be done?” is an important question and answered in the Strategy. However, „Where should be done?" in another important question missing within the Strategy and in its Master Plans. The facts that sector-specific propositions were not spatialized and that space was underestimated and neglected in these domains created disadvantages by achieving innovative local development as expected. This missing spatial dimension should be reconsidered in the future for the sake of local innovation capacity and economical development.

\section{BIBLIOGRAPHY}

Bölgesel İnovasyon Stratejisi Hazırlama Kılavuzu - Aşama 0, 2005, Avrupa Yenilikçi Bölgeler Ağ 1 , Mersin.

Bölgesel İnovasyon Stratejisi Hazırlama Kılavuzu - Aşama 2, 2007, Avrupa Yenilikçi Bölgeler A $\breve{g} 1$, Mersin.

Cooke P., 1992, Regional Innovation Systems: Competitive Regulation in the New Europe, „Geoforum”, 23(3), p. 365-382.

Cooke P., Uranga G.M., Etxebarria B., 1998, Regional Innovation Systems: An Evolutionary Perspective, „Environment and Planning A”, 30, p. 1563-1584.

Drucker F.P., 1985, Innovation and Entrepreneurship, William Heinemann, London.

Elçi Ş., 2007, Inovasyon: Kalkınmanın ve Rekabetin Anahtarı, Ankara.

Elçi Ş., Karataylı I., Karata S., 2008, Bölgesel Inovasyon Sistemleri: Türkiye İçin Bir Model Önerisi, „Yayın”, No. TÜSİAD-T/2008-12/477, Graphis Matbaa, Ankara.

Elliott J.E., 2005, Introduction to the Transaction Edition, [in:] Schumpeter J.A. (ed.), The Theory of Economic Development, Eleventh Printing, Transaction Publishers, New Brunswick.

Eraydin A., 2002, A Gateway Region That Looks For New Opportunities In Economic Development: The Assets And Problems Of The Region And The City of Mersin, [in:] The Problems of Urban Growth: Preserving While Developing, „Mimarlık Fakültesi Yayinları", 1, Mersin, p. 12-23.

Gök T., 2009, RIS Mersin Projesi Üzerine Bir Özet Değerlendirme, „Planlama”, 3-4, p. 93-95. Kara M., 2005, Cumhuriyetin İlk Yıllarında Mersin Limanı'nın Gelişimi, [in:] Tarih İçinde Mersin: Kollokyum II, „Mersin Üniversitesi Yayınları”, 14, Mersin, p. 130-135.

Köse S., 2002, 24 Ocak 1980 ve 5 Nisan 1994 İstikrar Programlarının Karşılaştırılması, [in:] Planlama Dergisi (DPT'nin Kuruluşunun 42. Y1lı Özel Sayısı), http://file.setav. org/Files/Pdf/24-ocak-1980-ve-5-nisan-1994-istikrar-tedbirlerinin-degerlendirilmesi. pdf (last accessed: May, 2015).

Levent T., 2009, 1980'lerden 2000’lere Mersin Ekonomik Yapısındaki Değişmeler, [in:] Mersin Sempozyumu 2008 Bildiriler Kitabı, Cilt 2, Mersin, p. 1125-1143. 
Levent T., 2010, Bir Hizmet Faaliyetinin Mekansallı̆ğ: Lojistik Sektörü İle İlgili İş Hizmetlerinin Mersin Kentindeki Mekansal Gelişimi Üzerine Görgül Bir Değerlendirme, „Planlama”, 3-4, p. 63-81.

Levent T., Sarıkaya Levent Y., 2010, Bölgesel Gelişmede Ulus-Devletin Rolü: 1999-2009 Yılları Arası Kamu Yatırımları Üzerinden Bir Değerlendirme, „Megaron”, 5(3), p. 1-13.

Levent T., Sarıkaya Levent Y., 2011, Türkiye'nin İlk Bölgesel Yenilik Stratejisi: RIS-Mersin Projesi, 1. Uluslararası Bölgesel Kalkınma Konferans1, 22-23 Eylül 2011, Malatya, p. 177-184.

Levent T., Sarıkaya Levent Y., 2013, RIS-Mersin Projesi ve Mersin Bölgesel Yenilik Stratejisi: Yenilik Üzerine Yerel Bir Değerlendirme, VII. Ulusal Coğrafya Sempozyumu, 18-19 Ekim 2012, TÜCAUM, Ankara Üniversitesi.

Mersin İli Turizm Master Planı, 2010, Barlas İmar Planlama Müşavirlik Ltd. Şti.

Mersin Inovasyon Stratejisi 2006-2016, 2008, Mersin.

Mersin Inovasyon Stratejisi ve Eylem Planı, 2008, Mersin.

Mersin Lojistik Strateji Planı, 2009, Maestro Danışmanlık AŞ ve Atilla Yıldıztekin, Mersin. Mersin Tarım Master Planı, 2011, Maestro Danışmanlık AŞ, Mersin.

Metin H., 2010, Social and Institutional Impacts of Mersin Regional Innovation Strategy: Stakeholders' Perspective, Basılmamış Yüksek Lisans Tezi, ODTÜ, Ankara.

Porter M.E., 1990, The Competitive Advantage of Nations, Free Press, New York.

Schmookler J., 1966, Invention and Economic Growth, Harvard University Press, Massachusetts.

Schumpeter J.A., 2005, The Theory of Economic Development, Eleventh Printing, Transaction Publishers, New Brunswick.

Steward D.J., 1996, Economic Recovery And Reconstruction In Postwar Beirut, „Geographical Review," 86(4), p. 487-504.

Türel A., 2002, Housing And Housing Industry In Mersin, [in:] The Problems of Urban Growth: Preserving While Developing, „Mimarlık Fakültesi Yayınları”, 1, Mersin, p. 1-11.

\section{PROJEKT RIS-MERSIN: PIERWSZA REGIONALNA STRATEGIA INNOWACJI W TURCJI I JEJ WYMIAR PRZESTRZENNY}

Zarys treści Mersin to stosunkowo młode miasto tureckie. Mimo, że jego historia sięga zaledwie XIX wieku, to już doświadczyło bardzo istotnych zmian w strukturze urbanistycznej i gospodarczej. Mersin jako miasto portowe jest główną bramą do Anatolii i na Bliski Wschód. Charakter Mersin ukształtował się poprzez budowę nowego portu w 1962 roku, a także orientację preferencji ekonomicznych w kierunku eksportu począwszy od 1980 roku. Rezultatem tych działań było zwiększenie obrotów handlowych, a także pojawienie się nowych działalności gospodarczych. Kolejne znaczące zmiany w lokalnej gospodarce miały miejsce po wojnie w Zatoce Perskiej w 1990 roku, kiedy to zanotowano radykalne spadki transakcji handlowych z krajami Bliskiego Wschodu. W 2006 roku stworzono dla Mersin pierwszą regionalną strategię innowacji w Turcji - RIS-Mersin, która miała na celu zmianę tendencji spadkowej 
lokalnej gospodarki oraz przyspieszenie rozwoju lokalnego. Strategia bazowała na idei innowacyjności jako kluczowego czynnika rozwoju lokalnego.

Celem niniejszego opracowania jest krytyczna ocena regionalnej strategii innowacji dla miasta Mersin i jej wymiaru przestrzennego w kontekście rozwoju lokalnego. Sukcesy i porażki tej strategii dostarczają ważnej lekcji dla innych regionów zmierzających do implementacji takich strategii.

Słowa kluczowe Mersin, regionalna strategia innowacji, wymiar przestrzenny.

Prof. Tolga Levent Mersin University Turkey 